\title{
The Unification Bonus (Malus) of East Germans After the Fall of the Berlin Wall
}

\author{
Miriam Beblo \\ Berlin School of Economics and Law \\ Irwin L. Collier \\ Freie Universität Berlin \\ Thomas Knaus \\ German Federal Ministry of Economics and Technology
}

\begin{abstract}
This paper presents estimates of the unification bonus for East Germans over the period 1991 to 1998. The unification bonus is defined as the discounted value of the difference between a person's actual income and his or her counterfactual real income stream forecast for a hypothetical continuation of economic life in a static GDR. Our central result is that nineteen percent of East Germans received a present value malus and so can be regarded as unification losers but that the aggregate bonus is ten times the size of the aggregate malus of the sample over this period.
\end{abstract}

- JEL Classification: D1, D3, P2

- Keywords: Real Income Comparison, Income Distribution and Mobility, Economies In Transition

\footnotetext{
*Corresponding address: Irwin Collier; John-F.-Kennedy Institute for North American Studies Freie Universität Berlin, Lansstr. 7-9, 14195 Berlin GERMANY, Tel: +49-30-838-53688, E-mail: irwin.collier @ fu-berlin.de

(C2012-Center for Economic Integration, Sejong Institution, Sejong University, All Rights Reserved.
} 
On the eve of German reunification, then Federal Chancellor Helmut Kohl made an unqualified claim that as a consequence of unification no one would be worse off and many would be much better off. ${ }^{1}$ This prediction that the coming social and economic revolution in Eastern Germany would lead to a Pareto improvement in the strict sense of having no losers was an expression of a widely shared hope as well as a rallying cry in the political struggle for future electoral share in the East. The issue is not whether to accept or reject such an extreme Paretian claim but instead to proceed in the spirit of poverty measurement: our goal is to identify those who could reasonably count themselves among the economic losers of German reunification (incidence) and to gauge the depth of their losses (unification gap). While armies of lawyers commanded by politicians dominated the economic policy decisions in the dramatic months following the fall of the Berlin Wall, economists had at least been able to salvage for themselves the claim to the first word in writing the economic history of that time. ${ }^{2}$ While this German question begs (and receives) a German answer, identical concerns regarding the distributions of the gains and losses of economic transition are found in all postsocialist economies. The methodology of this paper should be of general interest to economists interested in the empirics of transition.

The object of our empirical attention is what we have chosen to call the unification bonus defined as the present discounted value as of July 1, 1990 of the difference between an Eastern German individual's observed real income stream (adjusted for household composition) and the counterfactual real income stream that would have been experienced under a continuation of economic life in a static German Democratic Republic (GDR) through 1998. For lack of a better term, we call a negative bonus a unification malus. While there can be no doubt that such a measure of economic welfare should be systematically related to what is generally understood as the winners and losers from German unification, economic welfare is only one of several dimensions of social welfare. We hope that careful readers will share our reluctance to leap from the distribution of the unification bonus or

\footnotetext{
${ }^{1}$ Less well remembered is that Helmut Kohl was most explicit in including both eastern and western Germany in his "promise." The promise was made in Kohl's speech on June 21, 1990 before the Bundestag. It has been reprinted in Texte zur Deutschlandpolitik (1990:396).

${ }^{2}$ Comprehensive surveys of this dramatic economic history are found in Sinn and Sinn (1992), Siebert (1993), Akerlof, et al. (1991), and for a later account see Burda and Hunt (2001) who examined the productivity-wage-employment interrelationships.
} 
malus to the grand question of "winners" versus "losers" just quite yet. ${ }^{3}$ This said, we believe the principal contribution of this paper is that it offers the best estimates to date of the real income gains and losses in Eastern Germany following the reunification of Germany in 1990.

Previous economic studies that have examined the impact of reunification at the individual level have for the most part exclusively focused on nominal income mobility in East Germany. Krause and Habich (1993) looked at the changes in household income that took place during the early years of transition, Hauser and Fabig (1999) investigated labor and household income mobility between 1990 and 1995, and Steiner and Kraus (1996) analyzed the distribution of labor income from 1989 to 1993. All studies used the German Socioeconomic Panel. The main finding of these studies was that income mobility in the East was higher in the early years of transition and had approached the Western level over time. The probability of a falling relative position within the income distribution was higher for individuals and households who had experienced unemployment. Women were more at risk to end up in a lower income quantile than men. However, due to the lack of anything but extremely crude purchasing power parity indexes to link postGDR prices in Eastern Germany to GDR prices, there had been no satisfactory comparisons of GDR real incomes with real incomes after Monetary and Economic Union that took place July 1, 1990.

The problematic nature of existing purchasing power parities for converting the 1990 Eastern Mark into DM has been widely recognized throughout the literature. For example Hauser (1992: 62) explicitly mentions the existence of quantity constraints and the extensive use of subsidies in the former GDR that complicate comparisons of the purchasing power of money in divided Germany. Here is where the main contribution of the present paper is to be found: we are able to provide both forecasts of East German living standards, tailored to individual and household circumstances, as well as exact purchasing-power-parity indexes ${ }^{4}$ that

${ }^{3}$ Readers will also note that we often fail to take our own advice and in the interest of expository convenience will refer to winners and losers anyway. When we refer to winners we only mean a unification bonus greater than zero.

${ }^{4}$ Here "exact" is meant in the sense of the theory of the cost-of-living index à la Konüs rather than to suggest unwarranted statistical precision. Collier (2012) in this Journal uses a simple demand system estimated for West German household data to calculate DM-metric real-consumption values for observed East German quantity-constrained consumption bundles. Interested readers are referred to that paper for the technical details of the estimation of the parities used in this paper as well as for evidence of the convergence of the East German structure of consumer expenditure towards the pattern observed in West Germany. 
have been constructed from data collected by the German Federal Statistical Office linking post-GDR prices in Eastern Germany to prices in the GDR on the eve of German economic unification. In Figure 1 readers will find a plot of the deflators used to convert nominal expenditures for three different East German household types into $1991 \mathrm{DM}$ totals.

The household income data we analyze are taken from the German SocioEconomic Panel (GSOEP) that began to include Eastern German households (1,944 individuals are in our sample) even before German Economic, Monetary and Social Union actually went into effect on July 1, 1990. The assumption of a static GDR economy as the benchmark for our counterfactual has been chosen more for the psychological salience of the final year of the GDR economy than as a realistic forecast of an economy whose time is indeed running out. ${ }^{5}$ This by itself is sufficient reason to consider our estimate of the aggregate unification bonus as a lower bound for the true bonus. The assumption of static expectations has the additional merit of providing a simple way of exploiting the (single) cross-section of economic life reported in the first Eastern wave of GSOEP to generate counterfactual real income streams up through 1998, conditional on individual characteristics. We have assumed that as an individual's age, household composition, and job-related characteristics changed over the past decade, the relevant comparison for judging his or her relative gain or loss would be that to someone else with the same age and other individual characteristics in the 1990 sample.

We calculate the unification malus incidence of nineteen percent for the GSOEP sample of East Germans, aged 25 years and above at the time of German unification. For these individuals real income losses following German economic unification have indeed exceeded the gains. On the other hand, we also calculate that aggregate gains of the unification "winners" have swamped the aggregate losses of the "losers." Expressed as a present discounted value (valued in 1991 $\mathrm{DM}$ ) the average bonus of the $81 \%$ unification "winners" was over $39,000 \mathrm{DM}$ vs. the average unification loss of $15,700 \mathrm{DM}$ of the other $19 \%$ of our sample. The vast bulk of the unification malus had been concentrated in the cohorts that were between 35 and 54 years of age in 1990 with the largest unification bonuses going to those 55 years and older in 1990 .

\footnotetext{
${ }^{5}$ This is more or less the bottom line of the classified report prepared for the GDR's Politbüro dated October 30, 1989 prepared by the Chairman of the State Planning Commission, see Schürer (1992).
} 
We present in Section I our method for estimating the counterfactual income streams that East Germans could have expected under a static continuation of the GDR into the late 1990s. In Sections II and III we combine actual observations with appropriate deflators estimated in the companion paper Collier (2012) published in this journal together with our counterfactuals to generate estimates of the incidence and magnitude of the unification bonus or malus over time as well as by age and gender breakdowns. Given the exploratory nature of our estimates, we conclude the paper in Section IV with a summary and a discussion of certain structural weaknesses of our estimates that constitute suggestions for future research.

\section{Back in the GDR: Eastern Incomes in Hindsight}

To establish the baseline level of income for each individual in the sample, we use data from the German Socio-Economic Panel (GSOEP). ${ }^{6}$ While the original panel began in 1984 and was limited to a West German sample, the GSOEP was expanded to include households from East Germany in June 1990, hardly half a year after the Berlin Wall had fallen yet still before monetary and economic union went into effect the following month. The empirical results reported in this section are based on that initial 1990 wave of East Germans. Our purpose here is to use the GDR cross-section in order to construct a "statistical memory" of the distribution

Table 1. Sample selection

\begin{tabular}{lc}
\hline & Cases left in sample \\
\hline Respondents GSOEP 1990-1998 & 2528 \\
Interview conducted prior to July 1990 & 2409 \\
German nationality & 2403 \\
Respondents above age 25 & 2144 \\
Non-missing values for income & 2117 \\
Sample used for income estimation (excludes missing values 1990) & 2110 \\
Sample used for income forecast & 1944 \\
(excludes panel attrition for 1991-1998) & \\
Sample used for present value calculation & 1903 \\
(excludes missing values for actual incomes from 1991-1998) & \\
\hline
\end{tabular}

${ }^{6}$ For more information on the GSOEP, see Wagner, Burkhauser, and Behringer (1993) and Projektgruppe Sozio-oekonomisches Panel (1995). 
Figure 1. Deflators for East German households (1991 West German Price Level $=1.00$ )

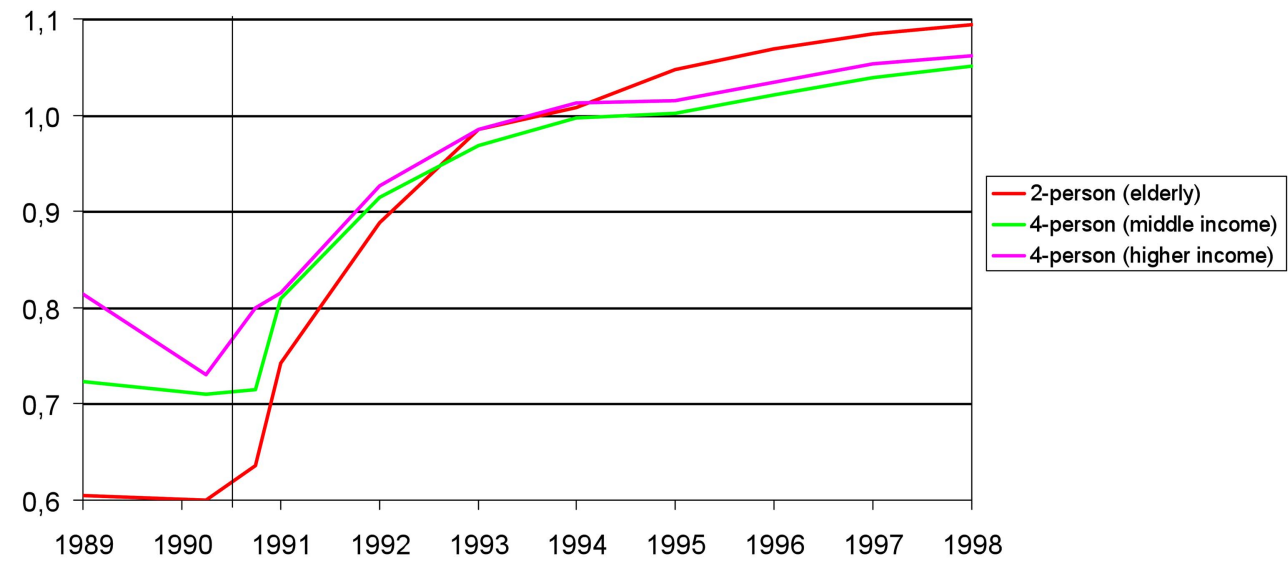

Source: Authors' calculations based on Collier (2012).

of nominal incomes broken down by personal characteristics on the eve of economic unification. ${ }^{7}$

Our sample selection criteria are listed in Table 1. The sample includes all East German respondents who participated in the survey in 1990 (before July) and remained in the panel each subsequent year through 1998. We limit the analysis only to German nationals. We have further restricted our sample to only include respondents 25 years and older at the time of unification. We have excluded the youngest adult cohorts to sidestep the considerable complication that would be introduced by including educational decisions in our counterfactuals. ${ }^{8}$ Observations with missing data for income or for any of the explanatory variables have also been dropped. The sample used for the income regression consists of 2,110 men and women ages 25 to 85. Descriptive statistics of this sample are provided in Table A1 of Appendix A. The final sample used for the projection of counterfactual income streams through 1998 is comprised of 1,944 men and women.

We calculate household equivalent income using the so-called "modified OECD equivalence scale" which assigns a weight of unity for the first adult living in a

\footnotetext{
${ }^{7} \mathrm{~A}$ small fraction of interviews were conducted after monetary union went into effect on July 1,1990 . We have only included respondents who participated in the panel before that date so that all income variables from 1990 are expressed in GDR marks.

${ }^{8}$ Access to higher education was severely rationed in the GDR and not according to criteria that a GSOEP survey was likely to capture.
} 
household and then adds 0.5 for each additional adult living in the household and/ or 0.3 for each non-adult under the age of 16 . This particular equivalence scale has been chosen largely because it appears with ever increasing frequency in the income inequality literature. Nonetheless it is with some trepidation that we use weights that have evolved for market economies to adjust the GDR household incomes. The theory and practice of computing household equivalence scales for centrally planned economies, where quantity constraints, in-kind benefits, and indirect taxation for distributive purposes all played a significant role, is entirely lacking at present so there is not much to do here beyond acknowledging this serious difficulty and moving on.

The natural logarithm of household equivalent income serves as the dependent variable in regressions running separately for women and men. The coefficient estimates are reported in Table 2. From these regressions we obtain our equivalized income forecasts. ${ }^{9}$

For explanatory variables we include age, schooling, additional education, job characteristics such as the occupational status, tenure, and whether someone is employed or receiving a pension. ${ }^{10}$ Other explanatory variables include one dummy variable for working in the manufacturing or production sector and another for living in Berlin.

One of the most important explanatory variables for predicting future equalized income is, of course, the individual's age. The shape of the age-income profile, however, strongly depends on the assumed underlying functional form of the relationship between age and equivalence income. By using a spline function one can better allow for non-linearities in this relationship while retaining a relatively simple specification. ${ }^{11}$ We have chosen a specification using a linear spline function with five different linear splines, corresponding to five age groups (25-34, $35-44,45-54,55-64,65$ years of age and older).

In Figure 2 we can see the resulting age-income locus for this specification. For the purpose of comparison, an age-income specification using a linear plus a

\footnotetext{
${ }^{9}$ Granting more than a passing resemblance, this specification should not be confused with Mincer-type earnings or wage equations. The crucial difference is in our goal of predicting household equivalent incomes and not individual earnings. Household equivalent income is the more appropriate measure for welfare comparisons which is what we are after.

${ }^{10}$ Our default category is "not participating in the labor force or unemployed".

${ }^{11}$ Linear splines capture the relationship between two variables as a piecewise linear function, in other words a function composed of linear segments joined at knots.
} 
Table 2. OLS regression: equivalized income (logarithm) in 1990

\begin{tabular}{|c|c|c|c|c|}
\hline & \multicolumn{2}{|c|}{ Women } & \multicolumn{2}{|c|}{ Men } \\
\hline & Coefficient & Robust & Coefficient & Robust \\
\hline & Estimate & Stand. Error & Estimate & Stand. Error \\
\hline \multicolumn{5}{|l|}{ Age group } \\
\hline $25-34$ & -0.0050 & 0.0043 & -0.0164 & 0.0051 \\
\hline $35-44$ & 0.0198 & 0.0033 & 0.0188 & 0.0037 \\
\hline $45-54$ & 0.0015 & 0.0041 & 0.0039 & 0.0039 \\
\hline $55-64$ & -0.0291 & 0.0075 & -0.0136 & 0.0058 \\
\hline Above 64 & -0.0154 & 0.0048 & -0.0171 & 0.0071 \\
\hline \multicolumn{5}{|l|}{ Schooling } \\
\hline \multicolumn{5}{|l|}{$\begin{array}{l}\text { (Basic level secondary } \\
\text { schooling, } 9 \text { years) }\end{array}$} \\
\hline No schooling & -0.2696 & 0.1436 & -0.1628 & 0.1812 \\
\hline $\begin{array}{l}\text { Middle secondary } \\
\text { schooling, } 10 \text { years }\end{array}$ & 0.0357 & 0.0251 & 0.0506 & 0.0218 \\
\hline $\begin{array}{l}\text { High school diploma, } \\
12 \text { years }\end{array}$ & 0.0710 & 0.0386 & 0.1561 & 0.0359 \\
\hline Other & 0.2003 & 0.0742 & -0.0062 & 0.0926 \\
\hline \multicolumn{5}{|l|}{ Additional education } \\
\hline \multicolumn{5}{|l|}{ (Apprenticeship) } \\
\hline No degree & -0.0863 & 0.0324 & -0.0086 & 0.0827 \\
\hline College degree & 0.0750 & 0.0222 & 0.0365 & 0.0248 \\
\hline University degree & 0.1649 & 0.0415 & 0.0671 & 0.0408 \\
\hline \multicolumn{5}{|l|}{ Employment status } \\
\hline Employed & 0.1927 & 0.0363 & 0.1959 & 0.0619 \\
\hline Pensioner & 0.1316 & 0.0652 & 0.1001 & 0.0787 \\
\hline \multicolumn{5}{|l|}{ Job characteristics } \\
\hline \multicolumn{5}{|l|}{$\begin{array}{l}\text { (Employees with high } \\
\text { qualification) }\end{array}$} \\
\hline Tenure & 0.0064 & 0.0027 & 0.0035 & 0.0026 \\
\hline Tenure squared & -0.0001 & 0.0001 & -0.0001 & 0.0001 \\
\hline Unskilled & -0.0902 & 0.0253 & -0.0472 & 0.0458 \\
\hline Skilled worker & -0.0807 & 0.0277 & -0.0064 & 0.0288 \\
\hline Master craftsman & 0.0902 & 0.0541 & 0.0195 & 0.0354 \\
\hline Farmer & -0.1026 & 0.0407 & -0.0873 & 0.0328 \\
\hline Self employed & -0.0765 & 0.0718 & 0.0143 & 0.0503 \\
\hline Executives & 0.1076 & 0.0464 & 0.1940 & 0.0463 \\
\hline \multicolumn{5}{|l|}{ Industrial sector } \\
\hline Production sector & -0.0239 & 0.0189 & -0.0456 & 0.0195 \\
\hline \multicolumn{5}{|l|}{ Region } \\
\hline Berlin & 0.0715 & 0.0346 & 0.1464 & 0.0319 \\
\hline Constant & 6.5959 & 0.0454 & 6.6757 & 0.0695 \\
\hline R-squared & 0.3485 & & 0.2707 & \\
\hline Observations & 1142 & & 968 & \\
\hline
\end{tabular}

Source: GSOEP, Sample C "German residents in the GDR", 1990.

Note: According to the F-test for women tenure and tenure squared are jointly significant at the 1 percent-level, for men tenure and tenure squared are jointly significant at the 10 percent level. 
Figure 2. Age-income profiles for women and men (monthly household income equivalence in East German marks)
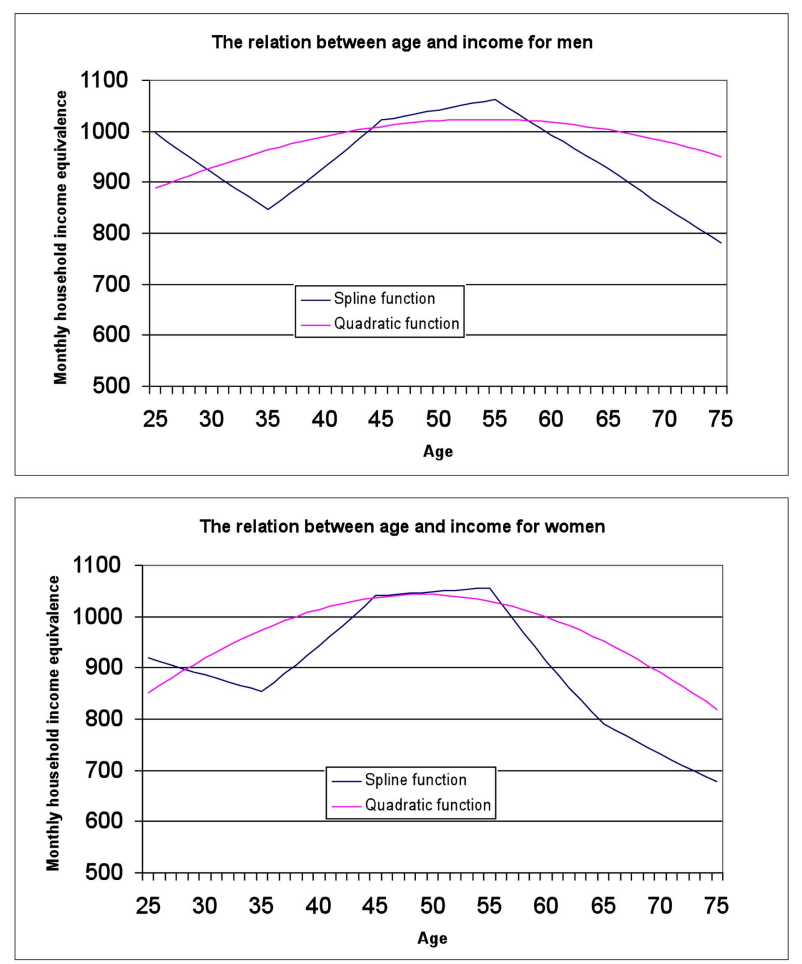

Source: Authors' calculations based on GSOEP wave 1990

quadratic age term is also shown. ${ }^{12}$ From these profiles it is obvious that a specification quadratic in age would not be sufficiently flexible to reflect the ageincome profile we actually observe. We see that our estimates reveal the first spline to have a negative relationship between age and equivalized income. ${ }^{13}$ This certainly reflects family formation and children that together work to lower these individuals' equivalized incomes quite substantially compared to their younger counterparts who are more likely to be single. This relationship between equivalent income and age plays an important role in the counterfactual income forecasts.

Schooling is in general significantly related with the income measure: the more

\footnotetext{
${ }^{12}$ Both curves belong to the profile of a person who worked as a skilled employee, having zero years of tenure and who falls into each of the reference categories used in the estimation equation for all remaining variables.

${ }^{13}$ Although this effect is not statistically significant, it is different from zero for women.
} 
schooling one has the higher the household equivalent income is. The same is true for formal training. Occupational status seems to be of more importance for women's income than for men's, judging from the calculated standard errors of the coefficient estimates. Both the linear and the quadratic terms of tenure are jointly significant for women only. Being employed raises equivalized income by $19.3 \%$ for women and $19.6 \%$ for men. ${ }^{14}$ The pensioner dummy shows an effect different from zero for female household equivalent income. The industrial sector dummy is only significant in the men's regression, where a job in the manufacturing or production sector is associated with lower income. Residing in East Berlin, the former capital of the GDR, has a positive effect for both women and men. East Berlin women are found to have a 7\% higher equivalized income compared to the rest of the GDR, whereas for East Berlin men the comparable difference is $15 \%$.

\section{Static Counterfactual}

In this section we combine the results from Section I and the price indexes calculated in Collier (2012) for the special circumstances of the economic integration of this former socialist economy with a market economy in order to produce real income forecasts and estimates of actual real incomes (valued at 1991 West German DM prices) for the years 1991-98. The critical assumption behind the forecasted counterfactual GDR incomes through the 1990s is that of static expectations. The estimated unification bonus will thus be a lower bound for the true magnitude since static expectations for a hypothetical GDR economy in the last decade of the twentieth century is by anyone's reckoning optimistic. We have experimented with three different variations of static expectations. For the first variant the word static is taken completely literally and we have simply assumed the same household equivalent income for each person in the sample for the years 1991 to 1998 as calculated from the GSOEP 1990 GDR wave. In the second variant we assume a constant annual income growth rate of $3 \%$. This rate is slightly lower than the reported growth of nominal incomes in the 1980s to allow for a slight hidden inflation. ${ }^{15}$ The third variant of income projections allows for

\footnotetext{
${ }^{14}$ The impact of the individual employment status turns out quite low due to the equalization procedure. Household equivalized income is less sensitive than individual income with respect to individual differences.

${ }^{15}$ This growth rate was calculated from Ministerrat der Deutschen Demokratischen Republik, Staatliche Zentralverwaltung für Statistik, Zentrales Zählbüro (1989).
} 
life-cycle variations in income within a static overall distribution. The single cross section of economic life reported in the first Eastern wave of GSOEP in 1990 along with the assumption of a static distribution is sufficient for us to generate counterfactual forecasts of life-cycle real income streams. All of our forecasts use the regression coefficients reported in Table 2.

In the forecasts for 1991-98 we distinguish between age-variant and ageinvariant variables, where the former variables are those that constitute the essence of the life cycle. Using the coefficients from the regression run on the 1990 eastern cross-section GSOEP data, we forecast the counterfactual incomes, assuming that the age-invariant variables do not change over time while the age-variant variables by definition would change in increments of one from year to year. As soon as a woman (man) reaches the pension age of 60 (65), both the participation and jobrelated dummies are set to zero as the pension dummy switches to unity. These ages are the modal 1990 East German pension age for women and men.

These forecast equivalized incomes are valued in 1990 East German marks as suits the counterfactual of a frozen GDR. They are then transformed using the deflators from Section I. Likewise the observed equivalized incomes have been transformed into 1991 German marks using deflators calculated for each year.

\section{Evolution and Distribution of the Unification Bonus (Malus)}

The difference between observed and forecast real equivalized monthly income is defined as a (flow) unification bonus (if positive) or malus (if negative). ${ }^{16}$ The present discounted value as of July 1, 1990 for the cumulative flow over the period 1991-98 may be regarded as a payment of a "cash welcome" (Begrüssungsgeld) ${ }^{17}$ if positive or as the price of admission to a free and democratic unified Germany if negative. While we prefer to use the unqualified "bonus" or "malus" to refer to the discounted value of the annual differences, it is simply too convenient to refer to the annual differences as bonuses or maluses and generally from the context it should be clear what is intended.

One of the central empirical results of this paper is the summary statistic that the proportion of East Germans with a present value unification malus through 1998 is

\footnotetext{
${ }^{16}$ Monthly rates have been converted into annual rates in all tables and figures.

${ }^{17}$ Even after the Berlin Wall opened on November 9, 1989 West Germany continued its established practice of granting every adult visiting from the east one hundred DM as a "cash welcome".
} 
$19 \%$, using a five percent real annual interest rate for discounting. This result, as all following, is based on the weighted income projection with the sample weights accounting for selection into the sample in 1990 and selection of staying in the panel until 1998. These calculations assume an individual perspective and not a household perspective and the persons are at least 25 years old in 1990. As can be seen from Table 1 our final sample consists of 1,903 persons.

The evolution of the annual incidence of a unification malus over time is displayed in Figure 3. It illustrates the very rapid decline of the share of "losers" in the first years following German social and monetary union in mid-1990. This first episode ends in 1994. From that time on malus incidence declines at a much slower speed and eventually in 1998 the trend even reverses. At this point in time it is not possible to tell whether this trend reversal is significant and/or continued.

Figure 3 also shows that basically all the three different measures calculated here yield more or less the same overall pattern. For the upper line of Figure 3 a three percent growth has been assumed. In this case the counterfactual obtained in the former GDR is on average larger so the bonus (malus) is smaller (greater in the sense of more negative). From Figure 3 we can see that income should have increased at least three percent p.a. in the former GDR for an increase over time of the malus incidence.

It can also be seen in Figure 3 that the bonus (malus) calculated with our life

Figure 3. Incidence of unification malus over time

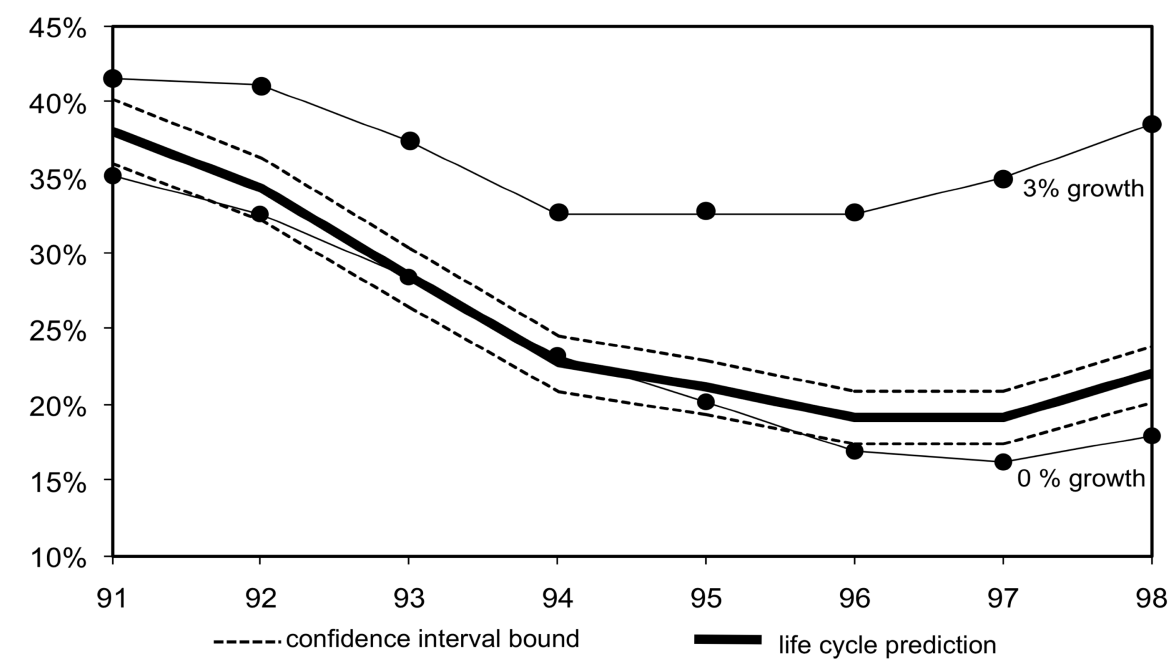

Source: Authors' calculations based on GSOEP waves 1990 to 1998 
cycle projection tracks quite closely the zero percent growth scenario. From the confidence bands drawn in the figure (dotted lines) it can be seen that our life cycle projection differs significantly from the zero growth scenario only at the very beginning in 1991 as well as the end of the time interval from 1996 onwards. In 1994 the proportion of "losers" is even higher (although not significantly) than in a scenario of zero percent growth which we see as the most mechanical manifestation of the static expectations assumption. This graph illustrates our life cycle projection as a compromise between the two mechanical growth rate scenarios of zero or three percent.

Having followed the time path of the incidence of a unification malus, we now turn to the evolution of the entire bonus/malus distribution over time. This can be seen in the left panel of Figure 4 where kernel densities ${ }^{18}$ of the unification bonus (malus) are plotted for 1991 and 1998. The areas under the curves and to the left of the origin are equal to the proportion of persons experiencing a unification malus for the particular year. This proportion fell from $38 \%$ in 1991 to $22 \%$ in 1998 . But so did the variance of the bonuses. The existence of a substantial proportion of "losers" from unification can be seen as unifying the results from the income inequality and income mobility literature discussed in the introduction.

Comparing the kernel densities of the present value of the cumulative annual bonuses for 1990-98 for women and men separately in Figure 4 (kernal densities on the right hand graph), one does not see a major difference between the sexes.

Figure 4. Kernel density estimates of the German unification bonus
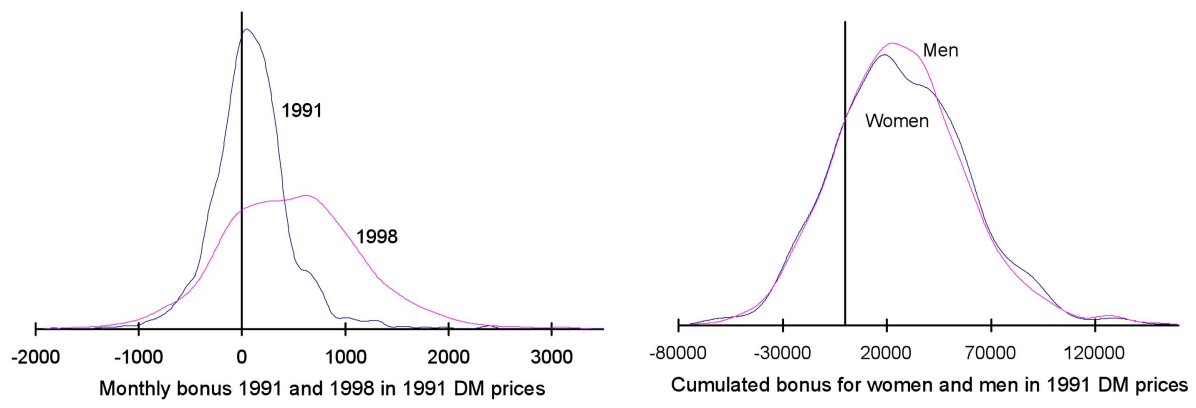

${ }^{18}$ For the kernel density estimation we used the Gaussian kernel. The density estimate is evaluated at 500 points and we used a bandwidth $h$ that was chosen optimally according to the formula $h^{\text {opt }}=0.9 \cdot m \cdot n^{-1 / 5}$ where $\mathrm{m}$ is the $\min (s, i / 1.349), s$ is the estimated standard deviation, $i$ the interquartile range, and $n$ is the sample size. 
Table 3. Unification malus incidence in 1991

\begin{tabular}{cccc}
\hline Age group (1990) & Women & Men & Total \\
\hline $25-34$ & 0.39 & 0.42 & 0.41 \\
$35-44$ & 0.38 & 0.42 & 0.40 \\
$45-54$ & 0.47 & 0.43 & 0.45 \\
$55-64$ & 0.37 & 0.49 & 0.42 \\
65 and above & 0.13 & 0.06 & 0.11 \\
All ages, 25 and above & 0.36 & 0.41 & 0.38 \\
\hline
\end{tabular}

Source: Authors' calculations based on GSOEP waves 1990 to 1998

Table 4. Unification malus incidence in 1998

\begin{tabular}{cccc}
\hline Age group (1990) & Women & Men & Total \\
\hline $25-34$ & 0.24 & 0.23 & 0.24 \\
$35-44$ & 0.45 & 0.34 & 0.39 \\
$45-54$ & 0.27 & 0.29 & 0.28 \\
$55-64$ & 0.03 & 0.09 & 0.06 \\
65 and above & 0.02 & 0.02 & 0.02 \\
All ages, 25 and above & 0.21 & 0.23 & 0.22
\end{tabular}

Source: Authors' calculations based on GSOEP waves 1990 to 1998

The mode of the distribution for women is a little bit lower and occurs at a somewhat lower value of the present value bonus.

Tables 3-7 provide a variety of present value summaries of net gains and losses for individuals using our life cycle forecast. ${ }^{19}$ Inspection of Tables 3 and 4 shows that the share of East Germans experiencing an annual unification malus has fallen from $38 \%$ in 1991 to $22 \%$ in 1998 . These are the numbers we also saw illustrated in Figures 3 and 4. Individuals relatively hardest hit over the past decade were people between the ages of 35 and 44 at the time of German unification. Indeed the women of those cohorts show the only increase in the proportion of "losers" between 1991 and 1998. In 1998 45\% of them experienced a net loss due to unification. Without a doubt the clear "winners" of unification were those retired or approaching retirement age upon the creation of the German monetary, economic, and social union. Indeed by 1998 it is pretty hard to find a Pareto loser among those men and women aged 55 and older in 1990.

${ }^{19}$ For comparison with the alternative counterfactuals in Appendix A we provide Tables A2 and A3 that are forecast equivalized incomes using the constant growth rates of 0 percent and 3 percent. 
Table 5. Incidence of a cumulative unification malus (negative present value of 1991-98 actual less forecast equivalized incomes)

\begin{tabular}{cccc}
\hline Age group (1990) & Women & Men & Total \\
\hline $25-34$ & 0.17 & 0.19 & 0.18 \\
$35-44$ & 0.30 & 0.27 & 0.29 \\
$45-54$ & 0.31 & 0.23 & 0.27 \\
$55-64$ & 0.07 & 0.17 & 0.11 \\
65 and above & 0.01 & 0.02 & 0.01 \\
All ages, 25 and above & 0.18 & 0.20 & 0.19 \\
\hline
\end{tabular}

Source: Authors' calculations based on GSOEP waves 1990 to 1998

Table 6. Present value as of July 1, 1990 of cumulative 1991-98 unification

bonuses/maluses

\begin{tabular}{ccccccc}
\hline & \multicolumn{7}{c}{ Mean present value gain } \\
Women & \multicolumn{9}{c}{ Men } & Total \\
\hline Age group & $\begin{array}{c}\text { 1991 DM } \\
\text { (West) }\end{array}$ & $\begin{array}{c}\text { relative to } \\
1990 \text { real } \\
\text { income }\end{array}$ & $\begin{array}{c}1991 \mathrm{DM} \\
\text { (West) }\end{array}$ & $\begin{array}{c}\text { relative to } \\
1990 \text { real } \\
\text { income }\end{array}$ & $\begin{array}{c}\text { 1991 DM } \\
\text { (West) }\end{array}$ & $\begin{array}{c}\text { relative to } \\
1990 \text { real } \\
\text { income }\end{array}$ \\
\hline $25-34$ & 26,346 & 1.69 & 26,233 & 1.69 & 26,290 & 1.69 \\
$35-44$ & 17,965 & 1.14 & 21,991 & 1.34 & 20,041 & 1.24 \\
$45-54$ & 20,685 & 1.20 & 25,684 & 1.50 & 23,098 & 1.35 \\
$55-64$ & 41,360 & 3.02 & 25,232 & 1.59 & 34,310 & 2.40 \\
65 and above & 50,668 & 4.65 & 51,422 & 4.14 & 50,906 & 4.49 \\
All, 25 and above & 30,057 & 2.18 & 27,080 & 1.75 & 28,675 & 1.98 \\
\hline
\end{tabular}

Source: Authors' calculations based on GSOEP waves 1990 to 1998

The entire course of annual unification bonuses and maluses from 1991 through 1998 are summarized in Table 5 . We see that $19 \%$ of our sample suffered a cumulative present value unification malus through 1998. We see the incidence of a unification malus is slightly greater for men than for women, although among the middle-aged cohorts women have been hit harder with the highest cell incidence in Table 5 of $31 \%$ "losers" found for 45 to 54 year-old women. One is also struck by the extremely small proportion of "losers" among the elderly.

No less important than the incidence of a unification malus is the average magnitude of the unification bonus which is tabulated in Table 6 for the same age/ sex groups as before. The present value of cumulative unification bonuses is expressed in 1991 DM West German prices and as a percent of real adult equivalent income in the GDR in 1990. For all age-gender combinations we see 
Table 7. Present value bonus and malus as of July 1, 1990 of cumulative 1991-98 unification bonuses/maluses

\begin{tabular}{ccccccc}
\hline & \multicolumn{3}{c}{ Mean present value bonus and malus in 1991 DM (West) } \\
\hline & \multicolumn{2}{c}{ Women } & \multicolumn{2}{c}{ Men } & \multicolumn{2}{c}{ Total } \\
\hline Age group & Bonus & malus & bonus & malus & bonus & malus \\
\hline $25-34$ & 34,144 & 12,259 & 36,991 & 18,705 & 35,531 & 15,674 \\
$35-44$ & 34,921 & 21,192 & 36,934 & 17,779 & 35,980 & 19,519 \\
$45-54$ & 36,107 & 14,336 & 38,122 & 16,456 & 37,133 & 15,205 \\
$55-64$ & 45,164 & 8,559 & 33,144 & 14,191 & 40,230 & 12,204 \\
65 and above & 51,249 & 6,217 & 53,196 & 18,926 & 51,859 & 12,947 \\
All, 25 and above & 40,154 & 15,385 & 38,220 & 17,168 & 39,267 & 16,258 \\
\hline
\end{tabular}

Source: Authors' calculations based on GSOEP waves 1990 to 1998

Figure 5. Cumulative distribution of the unification bonus (in Tsd. 1991 DM prices)

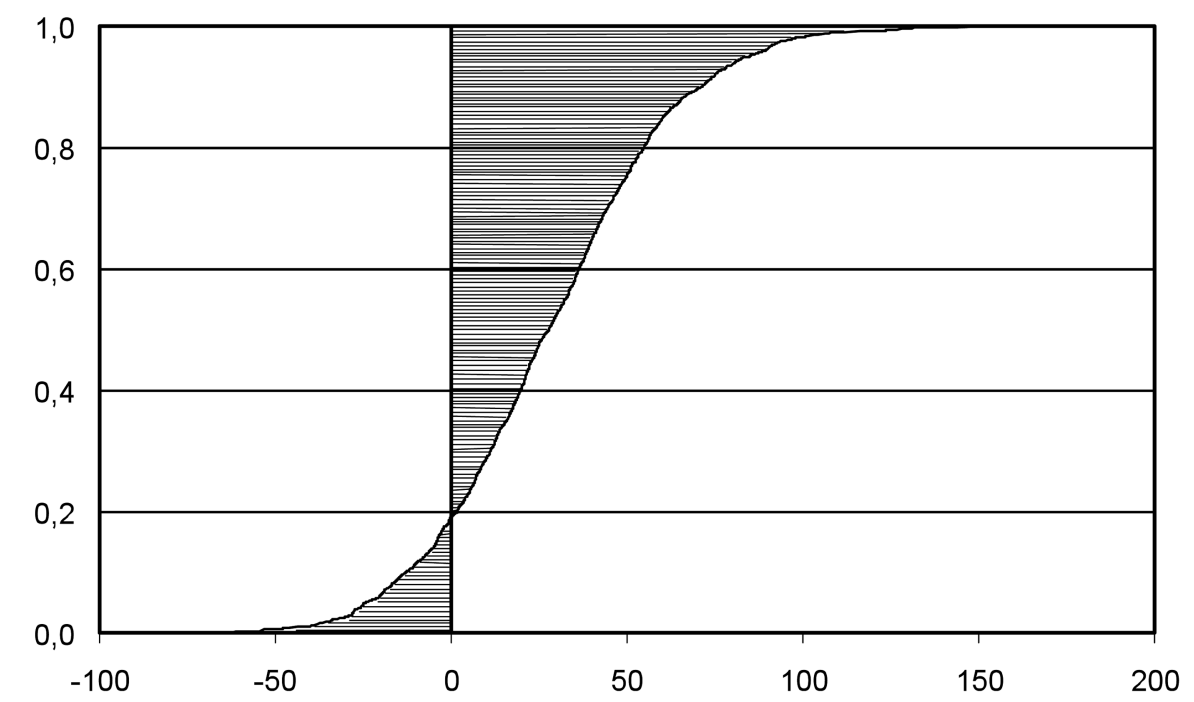

Source: Authors' calculations based on GSOEP waves 1990 to 1998

that there is in fact a positive net unification bonus on average, i.e., "winners" could have compensated losers" and remained "winners" in all cells of the table. One is also struck by the fact that the size of the average bonus of unification "winners" above the age of 65 at the time of economic unification is about 2.5 times larger than the corresponding figure for women "winners" between the ages of 35 and 44, that group with the lowest net average gain.

This same point can be illustrated somewhat differently in Table 7 which 
provides both the average unification bonus of "winners" and the average malus for "losers" again broken down by age and gender. We note that women "losers" between the ages of 35 and 44 at the time of German economic unification experienced the highest average net cumulative malus and that male "losers" above the age of 65 experienced an average unification malus three times that of women in the same age category. The main impression from an examination of Table 7 is that gender differences in size of the unification bonus are not nearly as striking as the differences according to age at the time of unification.

A vivid visual impression of the extent to which the unification gains have actually swamped the losses is provided by the cumulative distribution function of the present discounted value of the 1991-98 unification bonus (Figure 5). The CDF crosses the vertical axis at $19 \%$ which is the incidence of the unification malus in our sample. The shaded areas to the left and right of the vertical axis can be interpreted as the aggregate losses and gains respectively. The sum of cumulative present value bonuses is about ten times the magnitude of the sum of cumulative present value maluses.

\section{Conclusion}

This paper provides the first application of exact purchasing power parities between East and West Germany in order to provide a statistical picture of the evolution and distribution of the real economic gains and losses within the new federal states following German reunification. In contrast to previous studies, we have been able to correct two special aspects of GDR socialist reality that have prevented researchers from fully exploiting the unique 1990 nominal net household income data in East Germany from the GSOEP survey to compare with household income data from later surveys. The measurement of economic welfare attainable under the old GDR regime is greatly complicated by the fact that significant microeconomic quantity constraints (e.g. housing and automobiles) existed along with a system of indirect taxes and consumer price subsidies. Together these characteristics of GDR socialism meant that the relative purchasing power of the old GDR mark was quite different depending upon an individual's place in the income distribution. The deflators that we use, differentiated by equivalized income, are the keys needed to release the changes in economic welfare locked in the observed changes in nominal incomes.

We find a clear and overwhelming economic bonus on average for East 
Germans - a point which is to be expected. A large part of the story of postwall economic reconstruction is those who have suffered a unification malus, understood here as a negative present-value of annual differences between the course of actual income and a counterfactual forecast of income in a frozen GDR. About $19 \%$ of the East German population older than 25 in 1990 and who remained in the sample until 1998 is identified as having experienced a unification malus. Inspection of Figure 5 reveals that the aggregate unification malus is only about one-tenth the size of the aggregate unification bonus (seen by comparing the dark areas to the left and right of the zero line). We have also found that in contrast to what has been observed in other economies in transition from the old socialist order, elderly East Germans have gained much more than other age groups. Indeed for all intents and purposes, our sample of East German elderly survived the fall of communism in a way that both Helmut Kohl and Vilfredo Pareto could score as an improvement in economic welfare. At the other end of the bonus distribution, the smallest average unification bonus is found for women between the ages of 35 and 44 at the time of German unification. Thirty percent of that group is identified as unification "losers."

We are confident that our estimates of both the size and incidence of a unification malus represent upper bounds since they are calculated under the assumption of static expectations for our GDR counterfactual. The GDR economy has been riding a downward trend at the time of its political demise and few are so "ostalgic" as to believe that the GDR would have been able to maintain 1989 living standards over the past decade. Thus while we recognize the psychological salience of the last days of the GDR, as an economic matter we have almost certainly overstated the number of economic "losers" as well as the magnitude of their losses. Our attention has been limited to household income and its power to purchase consumer goods and services. The transformation of the East German economy of course involves a fundamental redefinition of many property rights. The capital gains from owning a modest family house on prime postwall land, the value of the family farm, or the loss of a bargain housing rental to the heirs of an expropriated owner are not touched upon in this paper. In particular we have not attempted to assess the unification bonus with respect to asset holdings - as opposed to equivalent income in this study - due to the lack of such data in the GSOEP. It is also important to add what may seem to be an obvious qualification given the title of the paper. We have nothing to say here about the unification bonus or malus for West Germans. Between four and five percent of West German 
GDP every year has been the size of the net West to East transfer during the first decade of German unification. Comparing the average East German welfare gains with the average West German losses is a most interesting question, though probably a better use of scarce research time would be to identify the policy mistakes that still left nearly one third of the East German potential working force in a social safety net financed by West Germany.

Having struggled to extract meaning from these data, we have an obligation to share two promising leads for future research.

- The issue of the appropriate equivalence scale within a market economy at a point in time is just about as subtle as any in the measurement of economic welfare (cf. Lewbel 1997). The modified OECD scale used here has only a single virtue: it ensures consistency with a vast empirical literature on income distribution. While we find ourselves in good company, we still believe that it is unlikely that one scale is going to fit all places and all times, least of all for economic transitions from central planning to market allocation. It is certainly our hope that future researchers will be able to remedy this weakness.

- While the deflators upon which our estimates of the unification bonus are based do attempt to correct for the spillover of demand across aggregate spending categories, say, from consumer electronics to alcoholic beverages, this is only part of the story. What is still missing is the breadth of product variety in a market economy that was missing in the centrally planned economies. For example one could travel, but as a general rule one could not travel on holiday in the West. What is the value of the introduction of that single "new product" with the fall of the Wall? This has been found to be an important shortcoming of traditional consumer price indexes for market economies, e.g., Hausman's (1999) study that documents the welfare gains from the introduction of the new product cell phones in the U.S. To that extent we have another good reason to believe that our estimates of unification "losers" are upper bound.

In spite of many good reasons to remain skeptical about the validity of the estimated unification bonus, one source of reassurance can be found in the results of direct public surveys. The German weekly newspaper DIE ZEIT ${ }^{20}$ on the occasion of the tenth anniversary of German unification in 2000 repeated an

${ }^{20}$ September $28,2000$. 
opinion survey of East Germans it conducted in 1993. The new survey found that the proportion of self-reported "losers" from unification had fallen from 24 to $19 \%$. Another survey on subjective well-being in East Germany asked whether individual living conditions improved or deteriorated since 1990 (Habich, Noll, and Zapf, 1999). In 1993 23\% of the respondents claimed a deterioration, but by 1998 this share had fallen to only $16 \%$. For those who might find the combination of econometrics, assumption, and data in this paper somewhat mysterious, perhaps the proportion of self-proclaimed unification "losers" from these public opinion surveys helps to demonstrate a broad consistency between quite disparate and independent sources of evidence.

\section{Acknowledgement}

Support from the Volkswagen Foundation is gratefully acknowledged. We thank Michael C. Wolfson, Thomas Zwick, and seminar participants in Berlin, Cracow, Houston, and Mannheim for their comments. Research for this paper was completed before Thomas Knaus entered government service and the views and conclusions presented here do not necessarily reflect German government views.

Received 2 December 2011, Revised 3 April 2012, Accepted 24 May 2012

\section{References}

Akerlof, George A., Rose, Andrew K., Yellen, Janet L. and Hessenius, Helge (1991), East Germany in from the Cold: The Economic Aftermath of Currency Union, Brookings Papers for Economic Activity, Vol. I, 1-101.

Burda, Michael C. and Hunt, Jennifer (2001), From Reunification to Economic Integration: Productivity and the Labor Market in Eastern Germany, Brookings Papers for Economic Activity, Issue 2.

Collier, Irwin L. (1986), Effective Purchasing Power in a Quantity Constrained Economy: An Estimate for the German Democratic Republic, Review of Economics and Statistics, 58(1), 24-32.

Collier, Irwin L. (1989), The Measurement and Interpretation of Real Consumption and Purchasing Power Parity for a Quantity Constrained Economy, The Case of East and West Germany, Economica, 56, 109-120.

Collier, Irwin L. (2012), The DM and the Ossi Consumer: Price Indexes during Transition, Journal of Economic Integration, 27(2), 245-273.

Habich, Roland; Noll, Heinz-Herbert and Zapf, Wolfgang (1999), Subjektives Wohlbefinden 
in Ostdeutschland nähert sich westdeutschem Niveau. Ergebnisse des Wohlfahrtssurveys 1998, in: ISI-Informationsdientst Soziale Indikatoren, Ausgabe 22, 1-6.

Hauser, Richard (1992), Die personelle Einkommensverteilung in den alten und neuen Bundesländern vor der Vereinigung - Probleme eines empirischen Vergleichs und der Abschätzung von Entwicklungstendenzen. In: Kleinhenz, G. (Ed.): Sozialpolitik im vereinten Deutschland II. Schriften des Vereins für Socialpolitik. Duncker \& Humblot. Berlin.

Hauser, Richard and Fabig, Holger (1999), Labor Earnings and Household Income Mobility in Reunified Germany: A Comparison of the Eastern and Western States, Review of Income and Wealth, 45(3), 303-324.

Hauser, Richard and Wagner, Gert (1996), Die Einkommensverteilung in Ostdeutschland Darstellung, Vergleich und Determinanten für die Jahre 1990 bis 1994. In: Hauser, R. (Ed.), Sozialpolitik im vereinten Deutschland III. Schriften des Vereins für Socialpolitik. Duncker \& Humblot. Berlin.

Hausman, Jerry (1999), Cellular Phones, New Products, and the CPI, Journal of Business and Economics Statistics 17(2), 188-194.

Krause, Peter and Habich, Roland (1993), Einkommensverteilung und Einkommens zufriedenheit in ostdeutschen Privathaushalten, DIW-Wochenbericht 6/93, 55-59.

Lewbel, Arthur (1997), Consumer Demand Systems and Household Equivalence Scales. In Pesaran, M.H. and P. Schmidt (Eds.): Handbook of Applied Econometrics. Volume II: Microeconomics. Blackwell Publishers.

Ministerrat der Deutschen Demokratischen Republik, Staatliche Zentralverwaltung für Statistik, Zentrales Zählbüro (1989), Haushaltseinkommen und Ausstattung der Haushalte von Arbeitern und Angestellten 1980-1988.

Projektgruppe Sozio-oekonomisches Panel (1995), Das Sozio-oekonomische Panel (SOEP) im Jahre 1994, Vierteljahreshefte zur Wirtschaftsforschung 64(1), 5-13.

Schürer, Gerhard (1992), Analyse der ökonomischen Lage der DDR mit Schlussfolgerungen. Deutschland Archiv 25 (October 1992): 1112-1120.

Siebert, Horst (1993), Das Wagnis der Einheit. Eine wirtschaftspolitische Therapie, 2. aktualisierte Neuauflage. Stuttgart, Deutsche Verlags-Anstalt.

Sinn, Gerlinde and Sinn, Hans-Werner (1992), Jump Start: the Economic Unification of Germany, Cambridge MA, MIT Press.

Steiner, Viktor and Kraus, Florian (1996), Aufsteiger und Absteiger in der ostdeutschen Einkommensverteilung: 1989-1993, in: Diewald, M. and K. U. Mayer (Eds.): Zwischenbilanz der Wiedervereinigung - Strukturwandel und Mobilität im Transformationsprozess, Opladen, 189-212.

Texte zur Deutschlandpolitik (1990), Reihe III/Band 8a.

Wagner, Gert; Burkhauser, Richard V. and Behringer, Friederike (1993), The Syracuse University English Language Public Use File of the German Socio-Economic Panel Study, The Journal of Human Resources 28(2), 429-433.

DIE ZEIT, September 28, 2000. 


\section{Appendix A}

Table A1. Sample characteristics, East Germans (25 years and older) in 1990

\begin{tabular}{|c|c|c|c|c|}
\hline & \multicolumn{2}{|c|}{ Women } & \multicolumn{2}{|c|}{ Men } \\
\hline & Mean & Stand. Dev. & Mean & Stand. Dev. \\
\hline \multicolumn{5}{|l|}{ Household characteristics } \\
\hline Children under 16 years in household & .48 & .50 & .50 & .50 \\
\hline Household size & 3.04 & 1.18 & 3.18 & 1.07 \\
\hline Total net household income & 1830.20 & 717.69 & 1956.90 & 637.50 \\
\hline Equivalized income (modified OECD-scale) & 977.71 & 301.69 & 1027.89 & 1009.42 \\
\hline \multicolumn{5}{|l|}{ Individual characteristics } \\
\hline Age & 44.90 & 13.57 & 43.73 & 12.04 \\
\hline \multicolumn{5}{|l|}{ Schooling } \\
\hline \multicolumn{5}{|l|}{$\begin{array}{l}\text { (Difference from basic level } \\
\text { secondary schooling, } 9 \text { years) }\end{array}$} \\
\hline No schooling & .003 & .05 & .004 & .06 \\
\hline Medium level secondary schooling, 10 years & .46 & .50 & .44 & .50 \\
\hline High school diploma, 13 years & .11 & .32 & .18 & .39 \\
\hline \multicolumn{5}{|l|}{$\begin{array}{l}\text { Additional education } \\
\text { (Difference from apprenticeship) }\end{array}$} \\
\hline No degree & .12 & .32 & .02 & .15 \\
\hline College degree & .24 & .43 & .27 & .44 \\
\hline University degree & .08 & .27 & .14 & .34 \\
\hline \multicolumn{5}{|l|}{ Employment status } \\
\hline Employed & .77 & .42 & .91 & .28 \\
\hline Pensioner & .15 & .36 & .06 & .23 \\
\hline \multicolumn{5}{|l|}{$\begin{array}{l}\text { Job characteristics } \\
\text { (Difference from employees with high qualification) }\end{array}$} \\
\hline Unskilled white/blue collar & .18 & .38 & .07 & .25 \\
\hline Skilled worker & .12 & .32 & .35 & .48 \\
\hline Master craftsman & .01 & .11 & .07 & .25 \\
\hline Farmer & .05 & .21 & .12 & .32 \\
\hline Self employed & .02 & .13 & .04 & .18 \\
\hline Executives & .01 & .11 & .03 & .17 \\
\hline Tenure & 10.15 & 10.33 & 13.84 & 11.60 \\
\hline \multicolumn{5}{|l|}{ Industrial sector } \\
\hline Production sector & .32 & .47 & .60 & .49 \\
\hline \multicolumn{5}{|l|}{ Region } \\
\hline Berlin & .07 & .25 & .07 & .25 \\
\hline Number of observations & 1142 & & 968 & \\
\hline
\end{tabular}

Source: Authors' calculations based on GSOEP wave 1990 
Table A2. Incidence of a cumulative unification malus (negative present value of 1991-98 actual less constant equivalized income)

\begin{tabular}{cccc}
\hline Age group (1990) & Women & Men & Total \\
\hline $25-34$ & 0.12 & 0.18 & 0.15 \\
$35-44$ & 0.14 & 0.18 & 0.16 \\
$45-54$ & 0.24 & 0.20 & 0.22 \\
$55-64$ & 0.20 & 0.28 & 0.24 \\
65 and above & 0.03 & 0.04 & 0.03 \\
All ages, 25 years and above & 0.15 & 0.19 & 0.17 \\
\hline
\end{tabular}

Source: Authors' calculations based on GSOEP waves 1990 to 1998

Table A3. Incidence of a cumulative unification malus (negative present value of 1991-98 actual less 3 percent per year trend equivalized income)

\begin{tabular}{cccc}
\hline Age group (1990) & Women & Men & Total \\
\hline $25-34$ & 0.33 & 0.32 & 0.32 \\
$35-44$ & 0.31 & 0.35 & 0.33 \\
$45-54$ & 0.37 & 0.34 & 0.36 \\
$55-64$ & 0.37 & 0.44 & 0.40 \\
65 and above & 0.09 & 0.08 & 0.08 \\
All ages, 25 years and above & 0.31 & 0.33 & 0.32 \\
\hline
\end{tabular}

Source: Authors' calculations based on GSOEP waves 1990 to 1998 